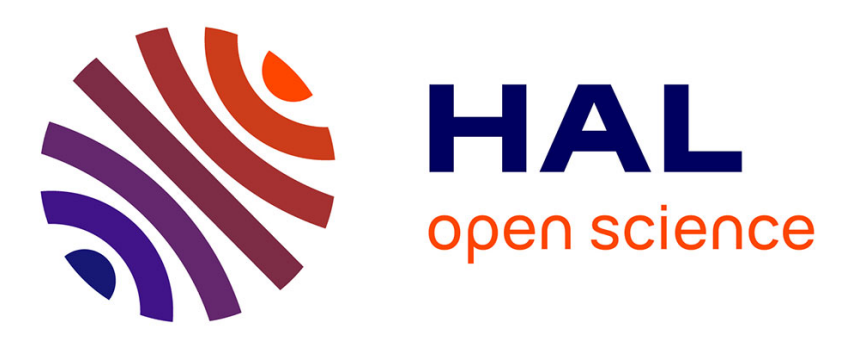

\title{
The procyclicality of loan loss provisions in Islamic banks
}

Wahyoe Soedarmono, Sigid Eko Pramono, Amine Tarazi

\section{To cite this version:}

Wahyoe Soedarmono, Sigid Eko Pramono, Amine Tarazi. The procyclicality of loan loss provisions in Islamic banks. 2016. hal-01319043

\section{HAL Id: hal-01319043 \\ https://hal-unilim.archives-ouvertes.fr/hal-01319043}

Preprint submitted on 20 May 2016

HAL is a multi-disciplinary open access archive for the deposit and dissemination of scientific research documents, whether they are published or not. The documents may come from teaching and research institutions in France or abroad, or from public or private research centers.
L'archive ouverte pluridisciplinaire HAL, est destinée au dépôt et à la diffusion de documents scientifiques de niveau recherche, publiés ou non, émanant des établissements d'enseignement et de recherche français ou étrangers, des laboratoires publics ou privés. 


\title{
The procyclicality of loan loss provisions in Islamic banks
}

\author{
Wahyoe Soedarmono* ${ }^{1}$, Sigid Eko Pramono**, Amine Tarazi*** \\ *Sampoerna University, School of Business, L'Avenue 6th Floor, \\ Jl. Raya Pasar Minggu, Jakarta 12780, Indonesia \\ ** Bank Indonesia, Department of Islamic Economics and Finance, Jl. MH. Thamrin \\ No.2, Jakarta 10350, Indonesia \\ ***Université de Limoges, LAPE, 5 Rue Félix Eboué, 87031 Cedex, France
}

\begin{abstract}
From a sample of Islamic banks around the world from 1997 to 2012, this paper examines whether loan loss provisioning in Islamic banks is procyclical. Our empirical findings highlight that loan loss provisioning in Islamic banks remains procyclical, although the 'expected' loan loss model (E-LLM) has been implemented for Islamic banks in several countries. A closer investigation further documents that Islamic banks also use loan loss provisions for discretionary managerial actions, especially related to capital management in which loan loss reserves and provisions are inflated when bank capitalization declines. Eventually, this paper highlights that higher capitalization can mitigate the procyclicality of loan loss provisions in Islamic banks. In other words, loan loss provisioning becomes countercyclical for Islamic banks with higher capitalization. This paper therefore casts doubts on the adoption of the E-LLM for Islamic banks to promote countercyclical effects, because the E-LLM may be influenced by managerial discretion, including opportunistic capital management using loan loss provisions that may undermine the importance of maintaining sufficient bank capitalization.
\end{abstract}

Keywords: Islamic banks, loan loss provisions, capital management, procyclicality JEL Classification: G15, G21, G28, M41

\footnotetext{
${ }^{1}$ Corresponding author.

Email: wahyoe.soedarmono@sampoernauniversity.ac.id (W.Soedarmono), sigidpram@bi.go.id (S.E. Pramono), amine.tarazi@ unilim.fr (A. Tarazi)
} 


\section{Introduction}

Since the onset of the 2008 global financial crisis, prudential regulation in banking has emphasized the need for a forward-looking model of bank credit risk management (Elnahass et al., 2016). It is widely admitted that when using a backward-looking model, banks tend to exacerbate procyclical effects by lowering credit standards during economic booms and hence, increasing the likelihood of financial distress (Bushman and Williams, 2012; Wezel, 2010). Similarly, banks also tend to become risk averse during economic downturns by tightening credit standards, which in turn deepens economic recessions.

In December 2011, the FSAB (Financial Accounting Standard Board) and the IASB (International Accounting Stardard Board) proposed a change in credit risk modeling for conventional banks using the 'expected' loan loss model (E-LLM) instead of the 'incurred' loan loss model (I-LLM) as described in Elnahass et al. (2016). As a matter of fact, the I-LLM was established following the IAS39 frameworks, where loan loss provisions are made after non-performing loans have materialized. In this context, the I-LLM is a backward-looking model that does not enable banks to create provisions during economic booms, which in turn triggers procyclical effects. Meanwhile, the E-LLM follows the IFRS9 frameworks in which loan loss provisions should be created before loans are disbursed, allowing banks to have sufficient provisions in good times in order to enable lending expansion during economic downturns.

For conventional banks, the adoption of the E-LLM has been delayed until 2018. Unlike in conventional banks, the E-LLM has been adopted by Islamic banks at least since 2010, particularly in countries adopting the AAOIFI (Accounting and Auditing Organization for Islamic Financial Institutions). In fact, the provisioning system enacted in the AAOIFI already follows the approach of the E-LLM (Sarea and Hanefah, 2013; Elnahass et al., 2016). Yet, the use of the E-LLM for Islamic banks is also mandatory for several countries that have adopted the AAOIFI, such as Bahrain, Jordan and Qatar (Zoubi and Al-Khazali, 2007; Taktak et al., 2010; Elnahass et al., 2016).

While the I-LLM is perceived to aggravate procyclical effects in bank lending, criticism over the E-LLM also occurs, because the E-LLM requires sophisticated valuations and relies substantially on managerial discretion. Elnahass et al. (2016) further emphasize three major critics of the E-LLM. First, relying on managerial 
discretion in projecting future cash flows and building up loan loss provisions using the E-LLM may undermine the need for a reliable and accountable financial report (Wezel, 2010; Ernst and Young, 2014a). Second, the E-LLM is less transparent than the I-LLM in terms of methodology and thus, the E-LLM enables banks to conceal a deteriorating loan portfolio. Third, the E-LLM also enables banks to smooth income due to a lack of transparency in the model, exacerbating risk taking during economic booms (Bushman and Williams, 2012).

In line with such criticism, a broad literature indeed highlights that conventional banks may use loan loss provisions for opportunistic managerial actions (Bouvatier and Lepetit, 2008 \& 2012; Anandarajan et al., 2007; Lobo and Yang, 2001; Ahmed et al., 1999). Nonetheless, previous studies also advocate the importance of a dynamic provisioning system using the E-LLM for conventional banks, although the E-LLM enables bank managers to act opportunistically. This is due to the fact that the current provisioning practice using the I-LLM remains procyclical for conventional banks, where higher macroeconomic performance tends to decrease loan loss provisions (e.g. Arpa et al., 2001; Cavallo and Majnoni, 2002; Laeven and Majnoni, 2003; Bikker and Metzemakers, 2005; Bouvatier and Lepetit, 2008 \& 2012).

In spite of a large number of works on the procyclicality of loan loss provisions for conventional banks, to the best of our knowledge, there is no prior literature highlighting whether loan loss provisioning in Islamic banks is also procyclical. Hence, analyzing the procyclical issues of loan loss provisions in Islamic banks is important for several reasons.

First, the distinctiveness of Islamic banks that comply with the precepts of Shariah Law makes the adoption of the AAOIFI and the E-LLM challenging, because Islamic banks have a unique business model, multi-layer governance and operational restrictions (Elnahass et al., 2016). For instance, Quittanah et al. (2011) shed light on the differences in accounting treatments among Islamic banks and hence, Islamic banks need to deal with unexpected losses due to such differences ${ }^{2}$. Fonseca and

\footnotetext{
${ }^{2}$ PLS (profit-loss sharing) contracts that basically have two types of investment account: Restricted Investment Account Holder (RIAH) and Unrestricted Investment Account Holder (UIAH). These contracts can be reported differently in bank income statement. For instance, Karim (2001) points out that some Islamic banks treat RIAH as equity or liability, while others consider it as off-balance sheet item.
} 
Gonzalez (2008) further point out that regulators require banks to absorb unexpected losses using bank capital, while expected losses need to be covered by loan loss provisions. In order to cope with unexpected lossess, Islamic banks are thus prone to opportunistic capital management using inflated loan loss reserves and provisions, because Islamic banks banks have limited funding access compared to conventional banks (Elnahass et al., 2016).

Second, given the above-mentioned doubts on the E-LLM implementation due to the influence of managerial discretion, and the fact that Islamic banks in several Middle-East countries already adopted the E-LLM since 2010 as part of the AAOIFI complience, it is therefore crucial to examine whether criticism on the E-LLM for Islamic banks around the world remains relevant. Yet, there is a growing number of studies advocating the advantage of the I-LLM instead of the E-LLM to mitigate opportunistic earnings management using loan loss provisions, although the I-LLM may still suffer from procyclical effects (Wezel, 2010; Bushman and Williams, 2012).

Third, Islamic banks have grown rapidly. Worldwide, the total assets of Islamic banking have reached USD 1.2 trillion in 2015 with an estimated annual growth of 10-15\% (Ernst \& Young, 2015), while Cevic and Charap (2011) document that Islamic banks' total assets only reached USD 939 billion in 2010. Such a rapid development suggests an increasing role of Islamic banks in the process of economic development. Accordingly, addressing the procyclicality issues of loan loss provisions in Islamic banks should also be more of a concern in order to prevent execessive risk taking during economic booms and strengthen the capacity to spur lending activities in times of crisis, notwithstanding the importance of mitigating opportunistic bank management behavior using loan loss provisions.

Given such motivations, our contribution in this paper is twofold. Firstly, we examine the impact of economic growth on loan loss provisions in Islamic banks and hence, highlight whether or not loan loss provisioning in Islamic banks around the world is procyclical. Secondly, we augment the analysis by assessing whether overcoming discretionary managerial behavior using loan loss provisions, as part of the enhancement of good governance in Islamic banks, may affect the link between economic growth and loan loss provisions itself. In this regard, assessing the influence of discretionary managerial behavior during economic expansionary periods might indicate whether or not the use of the E-LLM affected by certain managerial 
discretions can be detrimental to promoting the countercyclicality of loan loss provisions in Islamic banks.

Building on the prior literature for conventional banks (e.g. Bouvatier and Lepetit, 2008 \& 2012; Anandarajan et al., 2007), this paper focuses on the influence of three major discretionary managerial actions using loan loss provisions. These include capital management, income smoothing, and signaling. In terms of capital management using loan loss provisions, relying on bank managerial discretion in building up loan loss provisions may allow banks to inflate loan loss reserves, particularly for banks with capital ratios close to violating minimum capital requirements (Anandarajan et al., 2007). Loan loss provisions can also be used by bank managers to smooth income, because lower earnings volatility tend to convey a positive signal to investors that bank riskiness remains manageable (e.g. Collins et al., 1995; Ahmed et al., 1999; Anandarajan et al., 2007). The signaling theory also postulates that loan loss provisions can be used as a tool to for signaling future earnings (e.g. Beaver and Engel, 1996; Ahmed et al., 1999; Anandarajan et al., 2007).

The remainder of this paper is organized as follows. Section 2 presents our data and hypotheses development. Section 3 presents our methodology and variables. Section 4 describes empirical results, while Section 5 concludes the paper.

\section{Data and hypotheses development}

\subsection{Data sources}

For the purpose of this study, we retrieve a sample of 146 Islamic banks around the world from 1997 to 2012 covered by BankScope Fitch IBCA. Specifically, we retrieve balance sheet and income statement information of Islamic banks from the following countries: United Arab Emirates (10), Bangladesh (2), Bahrain (19), Brunei Darussalam (1), Egypt (2), UK (5), Gambia (1), Indonesia (3), Iraq (6), Iran (16), Jordan (3), Kuwait (9), Cayman Islands (1), Lebanon (3), Mauritania (2), Maldives (1), Malaysia (17), Philippines (1), Pakistan (9), Palestinian Territory (2), Qatar (4), Russia (1), Saudi Arabia (4), Sudan (12), Singapore (1), Syiria (2), Tunisia (1), Turkey (4), and Yemen (4) $)^{3}$. We also include macroeconomic data such as real gross domestic product obtained from the World Bank.

\footnotetext{
${ }^{3}$ The number of banks are in parentheses.
} 


\subsection{Hypothesis development}

As stated earlier, the objective of this study is twofold. First, we aim to test whether the procyclicality of loan loss provisions actually occurs by running regressions of loan loss provisions on economic growth as the explanatory variable of interest. Second, we test whether the procyclicality of loan loss provisions is conditional on Islamic banks' discretionary managerial action comprising capital management, income smoothing and signaling. For such purposes, we specify Hypothesis 1 and Hypothesis 2 to tackle the first and second objective, respectively:

Hypothesis 1: Islamic banks hold lower loan loss provisions following higher economic growth and hence, loan loss provisioning in Islamic banks remains procyclical.

Hypothesis 2 : The effect of economic growth on loan loss provisions depends on the extent to which Islamic bank managers act opportunistically using loan loss provisions for capital management, income smoothing or signaling.

Previous studies indeed document that discretionary capital management may affect loan loss provisioning behavior of banks (Bouvatier and Lepetit, 2008; Parker and Zhu, 2012). Bouvatier and Lepetit (2008) report that banks with poor capitalization are less inclined to build up loan loss provisions, while Parker and Zhu (2012) show that income smoothing strategies tend to be adopted in well-capitalized banks in Japan and poorly-capitalized banks in India. In this context, the role of bank capital management and income smoothing can not be separated in examining the issues of procyclicality in banking. Phrased differently, aside from capital management, income smoothing using loan loss provisions should also be examined regarding its impact on the procyclicality of loan loss provisions. In parallel, signaling strategies using loan loss provisions are also somehow related to income smoothing strategies, as banks may signal their strength when they can generate higher profits and, thus, loan loss provisions. For such reasons, Hypothesis 2 considers not only the discretionary behavior of Islamic related to capital management, but also income smoothing and signaling to examine whether the impact of economic growth on loan loss provisions depends on managerial discretion.

\section{Methodology and variables}


The methodology used in this paper comprises two stages. In the first stage, we test for the possible presence of a procyclical effect of loan loss provisions as stated in Hypothesis 1, while the second stage is to examine whether capital management, income smoothing or signaling using loan loss provisions during economic boom can exacerbate or offset the procyclicality of loan loss provisions as in Hypothesis 2.

Hypothesis 1 can be tested using the following equations in which we introduce the one-year-lagged value of the dependent variable as a regressor.

$$
\begin{aligned}
& \operatorname{LLPTA}_{i, t}=\alpha_{0} \text { LLPTA }_{i, t-1}+\alpha_{1} \text { LTA }_{i, t}+\alpha_{2} N P L_{i, t}+\alpha_{3} G R O W T H+\varepsilon_{i, t} \\
& \text { LLRTA }_{i, t}=\alpha_{0} \text { LLRTA }_{i, t-1}+\alpha_{1} \text { LTA }_{i, t}+\alpha_{2} N P L_{i, t}+\alpha_{3} G R O W T H+\varepsilon_{i, t}
\end{aligned}
$$

In Eq. (1a) and Eq. (1b), we merely focus on the determinants of loan loss provisions that may reflect non-discretionary behavior of bank managers, because the procyclicality of loan loss provisions is mostly related to the non-discretionary component of loan loss provisions (Bouvatier and Lepetit, 2008 \& 2012). On the other hand, adding more variables reflecting the discretionary component of loan loss provisions into Eq. (1a) and Eq. (1b) reduces the degree of freedom when we only have a limited number of Islamic banks available in our sample. From Eq. (1a), LLPTA is the ratio of loan loss provisions to total assets. For robustness considerations, we also use the ratio of loan loss reserves to total assets (LLRTA) as a dependent variable in Eq. (1b). LTA is the ratio of total loans to total assets, while $N P L$ is the ratio of non-performing loans to total loans and GROWTH is the real gross domestic product growth at the country level.

In the next turn, Hypothesis 2 can be tested using the following equations in which we add interaction terms between economic growth and a proxy of discretionary managerial actions in Islamic banks related to capital management, income smoothing and signaling.

$$
\begin{aligned}
\operatorname{LLPTA}_{i, t} & =\alpha_{0} \operatorname{LLPTA}_{i, t-1}+\alpha_{1} \text { LTA }_{i, t}+\alpha_{2} N P L_{i, t}+\alpha_{3} G R O W T H+ \\
& +\alpha_{4} C A P+\alpha_{5} C A P^{*} G R O W T H+\varepsilon_{i, t} \\
\text { LLRTA }_{i, t} & =\alpha_{0} L^{L P T A} A_{i, t-1}+\alpha_{1} L T A_{i, t}+\alpha_{2} N P L_{i, t}+\alpha_{3} G R O W T H+ \\
& +\alpha_{4} C A P+\alpha_{5} C A P^{*} G R O W T H+\varepsilon_{i, t}
\end{aligned}
$$




$$
\begin{aligned}
& \text { LLPTA }_{i, t}=\alpha_{0} \text { LLPTA }_{i, t-1}+\alpha_{1} \text { LTA }_{i, t}+\alpha_{2} N P L_{i, t}+\alpha_{3} \text { GROWTH }+ \\
& +\alpha_{4} E B T P+\alpha_{5} E B T P * G R O W T H+\varepsilon_{i, t} \\
& \operatorname{LLRTA}_{i, t}=\alpha_{0} \mathrm{LLPTA}_{i, t-1}+\alpha_{1} \mathrm{LTA}_{i, t}+\alpha_{2} N P L_{i, t}+\alpha_{3} \text { GROWTH }+ \\
& +\alpha_{4} E B T P+\alpha_{5} E B T P^{*} G R O W T H+\varepsilon_{i, t} \\
& \operatorname{LLPTA}_{i, t}=\alpha_{0} \mathrm{LLPTA}_{i, t-1}+\alpha_{1} \mathrm{LTA}_{i, t}+\alpha_{2} N P L_{i, t}+\alpha_{3} \text { GROWTH }+ \\
& +\alpha_{4} S I G N+\alpha_{5} S I G N * G R O W T H+\varepsilon_{i, t} \\
& \operatorname{LLRTA}_{i, t}=\alpha_{0} \text { LLPTA }_{i, t-1}+\alpha_{1} \text { LTA }_{i, t}+\alpha_{2} N P L_{i, t}+\alpha_{3} \text { GROWTH }+ \\
& +\alpha_{4} S I G N+\alpha_{5} S I G N * G R O W T H+\varepsilon_{i, t}
\end{aligned}
$$

Eq. (2a) and Eq. (2b) contain the interaction terms between capitalization and economic growth $\left(C A P^{*} G R O W T H\right)$ in order to examine the role of discretionary managerial actions related to capital management, in affecting the impact of economic growth on loan loss provisions. $C A P$ is defined as the ratio of total equity to total assets. Meanwhile, the role of income smoothing related discretionary managerial actions in affecting the link between economic growth and loan loss provisions is estimated using Eq. (2c) and Eq. (2d). In these equations, we incorporate the interaction terms between income smoothing and economic growth $\left(E B T P^{*} G R O W T H\right) . E B T P$ is the income smoothing variable defined as the ratio of earning before tax and provisions divided by total assets following Bouvatier and Lepetit (2008). Finally, Eq. (2e) and Eq. (2f) contain the interactions term between a signaling measure and economic growth $\left(S I G N^{*} G R O W T H\right)$, which aims to investigate how signaling managerial behavior affects the link between economic growth and loan loss provisions. SIGN captures signaling behavior, which is measured by:

$$
S I G N_{i, t}=\frac{E R_{i, t+1}-E R_{i, t}}{0.5\left(T A_{i, t+1}+T A_{i, t}\right)}
$$

$E R$ is defined as earnings before tax and loan loss provisions, while $T A$ is total assets. Again, we follow Bouvatier and Lepetit (2008 \& 2012) in measuring the abovementioned signaling behavior. This variable basically reflects the share of one-yearahead-change of earnings before taxes and loan loss provisions in total assets, where higher values indicate that the power of generating future earnings is strong enough to absorb potential losses. Banks conducting signaling will build up loan loss provisions 
due to higher prospects of future earnings in order to convey signals to the market that they behave prudently.

Overall, we estimate Eq. (1a) to Eq. (2f) using dynamic panel data techniques for several reasons. First, the current loan loss provisioning behavior might be affected by the last year's provisioning behavior due to managerial learning and, thus, the loan loss provisions variable is a dynamic rather than static variable. Therefore, the use of dynamic panel data techniques is relevant to control for dynamic movements of loan loss provisions. Second, loan loss provisions can be affected by explanatory variables introduced from Eq. (1a) to Eq. (2f), but those explanatory variables can also be affected by loan loss provisions. If this is the case, reverse causality problems might be an important drawback that requires particular attention. The use of dynamic panel data methodology is also relevant, because it can avoid reverse causality problems between loan loss provisions and their determinants.

In terms of econometric procedure, we follow Blundell and Bond (1998) to estimate dynamic panel data models as shown in Eq. (1a) - Eq.(2f). This method is referred to as the two-step system GMM estimation or the system GMM. The system GMM is shown to be more efficient than the standard GMM (Baltagi, 2005). We further consider orthogonal transformations of instruments to control for possible cross-sectional fixed effects, while we also include Windmeijer's (2005) finite sample correction to ensure for the validity of the system GMM. Finally, the system GMM is valid when both the $\operatorname{AR}(2)$ and Hansen-J test are not significant, indicating that there is no second order autocorrelation among errors, and overidentifying restrictions are valid, respectively.

\section{Empirical results}

\subsection{Results discussion}

In Table 1, we present descriptive statistics of the variables used in this study. No potential outliers can be detected, as the values of each variable seem economically plausible. We also eliminate all zero values for each variable to ensure that unavailable data is not treated as zero in our model estimations. Meanwhile, Table 2 presents the correlation structure of all variables. We can notice that all the independent variables presented from Eq. (1a) to Eq. (2f) are not highly correlated and hence, potential multicollinearity problems are less likely to occur. 
Considering the orthogonal deviations transformation of instruments in the system GMM estimation, Table 3 then documents that Islamic banks indeed use loan loss provisions for non-discretionary purposes in which higher loan-to-asset ratio (LTA) and non-performing loans (NPL) are associated with higher loan loss provisions. These results are consistent with prior literature on the procyclicality of loan loss provisions in conventional banks (e.g. Bouvatier and Lepetit, 2008 \& 2012; Bikker and Metzemakers, 2005).

\section{[Insert Table 3 here]}

Moreover, we also find that loan loss provisions of Islamic banks are procyclical, because higher economic growth deteriorates loan loss provisions as shown in Table 3. Although our sample period already covers 2012, when at least three countries (i.e. Bahrain, Jordan, and Qatar) had implemented the E-LLM as part of the AAOIFI complience as of 2010 (Elnahass et al., 2016), the fact that procyclical issues still occur may cast doubts on the effectiveness of the E-LLM to promote the countercyclicality of loan loss provisions. Yet, the coefficients of economic growth $($ GROWTH $)$ in Table 3 are not only statistically significant at the 5\% and $1 \%$ levels using either LLPTA and LLRTA as a dependent variable, respectively; they are also economically important.

If we use LLPTA as a measure of loan loss provisions, a one-standard deviation increase in economic growth (GROWTH) leads a decline in loan loss provisions by $8.73 \%$ of its mean (from $0.76 \%$ to $0.69 \%$ ). Provided the standard deviation of GROWTH equals to $0.5 \%$, this result can also be interpreted by indicating that a $1 \%$ increase in economic growth (i.e. a two-standard deviation increase in GROWTH) is associated with a decline in loan loss provisions by $17.4 \%$ of its mean (from $0.76 \%$ to $0.63 \%$ ). Similarly, if we use LLRTA as a measure of loan loss reserves, a one-standard deviation increase in economic growth deteriorates loan loss reserves by $7.2 \%$ of its mean (from $2.6 \%$ to $2.4 \%$ ). Phrased differently, a $1 \%$ increase in economic growth tends to deteriorate loan loss reserves by $14.4 \%$ of its mean (from $2.6 \%$ to $2.2 \%$. 
From these results, Hypothesis 1 is therefore not rejected, suggesting that Islamic banks' loan loss provisions is procyclical. Our dynamic panel data models to test Hypothesis 1 are also valid, because both the AR(2) and Hansen-J test are not significant. Such procyclical behavior of Islamic banks in building up loan loss provisions is indeed consistent with the results obtained for conventional banks in prior literature described earlier (Arpa et al., 2001; Cavallo and Majnoni, 2002; Laeven and Majnoni, 2003; Bikker and Metzemakers, 2005; Bouvatier and Lepetit, $2008 \& 2012)$.

Furthermore, we present our empirical results to test Hypothesis 2 in Table 4. Model 1 is addressed to test whether capital management behavior using loan loss provisions affects the procyclicality of loan loss provisions, while Model 2 and Model 3 are to test the impact of income smoothing and signaling behavior using loan loss provisions on the procyclicality of loan loss provisions, respectively.

\section{[Insert Table 4 here]}

From Table 4, it is shown that higher loan loss provisions are still affected by the loan-to-assets ratio (LTA) and non-performing loans (NPL). In this context, the use of loan loss provisions for non-discetionary purposes as discussed earlier is not altered. Meanwhile, economic growth (GROWTH) still has a negative impact on loan loss provisions (LLPTA) or loan loss reserves (LLRTA) and hence, loan loss provisioning remains procyclical in this regard. Moreover, Table 4 further highlights that Islamic bank managers also use loan loss provisions only for opportunistic capital management (Model 1), but not for earnings management (Model 2) or signaling (Model 3).

As the link between CAP and LLPTA (or LLRTA) is negative, this also means that loan loss provisions (LLPTA) or loan loss reserves (LLRTA) are inflated due to a decline in bank capital ratio $(C A P)$, a result that is consistent with Anandarajan et al. (2007). If we use LLPTA as the dependent variable, a one standard deviation decline in the capital ratio leads to an increase in loan loss provisions by $40 \%$ of its mean (from $0.74 \%$ to $0.45 \%$ ). If LLRTA is used as the dependent variable, a one standard deviation decline in the capital ratio leads to an increase in loan loss reserves by $11.8 \%$ of its mean (from $2.6 \%$ to $2.9 \%$ ). It is also shown that the link between bank 
capital ratio and loan loss provisioning is not only statistically significant as in Table 4 , but is also economically noteworthy.

Despite the negative link between bank capitalization and loan loss provisioning, indicating opportunistic capital management behavior, we find that the coefficient of the interaction term between bank capitalization and economic growth $\left(C A P^{*} G R O W T H\right)$ becomes positive as reported in Model 1 (Table 4). This positive coefficient also has a higher value than the absolute values of the negative coefficients of $C A P$ and $G R O W T H$ as standalone variables.

Compared to the negative coefficient of $C A P$, the positive coefficient of $C A P^{*} G R O W T H$ indicates that opportunistic capital management practices using loan loss provisions dissapear when economic growth reaches a certain level (i.e. $6.8 \%$ or $6.3 \%$ when we use LLPTA or LLRTA as the dependent variable, respectively). Although higher economic growth may mitigate the extent to which opportunistic capital management takes place using loan loss provisions in Islamic banks, economic growth is an exogenous factor that cannot be controlled by bank management. Accordingly, it is rather difficult to rely on higher economic growth, particulary following the 2008 global financial crisis, in order to deal with opportunistic capital management using loan loss provisions.

Similarly, the results presented in Model 1 (Table 4) further imply that the procyclicality of loan loss provisioning can be mitigated at least after a certain level of sufficient bank capital ratio has been reached, which may in turn prevent opportunistic bank management behavior to inflate loan loss reserves and provisions (Anandarajan et al., 2007). For instance, if LLPTA is used as the dependent variable, the negative impact of GROWTH on loan loss provisions indicating the procyclicality of loan loss provisions occurs when CAP is less than $24 \%$. On the contrary, the countercyclical effect of loan loss provisions occurs when CAP exceeds $24 \%$ in which higher economic growth is linked to higher loan loss provisions. If LLRTA is used as the dependent variable, the cut off point remains unclear, but higher economic growth leads to higher loan loss reserves for banks holding more capital $(C A P)$ in general.

Overall, loan loss provisions in Islamic banks may be countercyclical for wellcapitalized banks, provided that such banks do not suffer from opportunistic managerial behavior related to capital management using loan loss provisions when bank capital is high enough to mitigate such behavior. Finally, our models estimated in Table 4 are valid (the AR(2) test and the Hansen-J test are not significant). 


\subsection{Robustness checks}

In order to ensure the robustness of our empirical models, we modify the specification of our dynamic panel data models. Specifically, we follow Bouvatier and Lepetit (2008) by considering first-difference transformation instead of the orthogonal deviation transformation of instruments. Table 5 and Table 6 present our results using this new specification. On the whole, the empirical results discussed earlier are not altered. All dynamic panel data models using first difference transformation of instruments are still valid ( the AR(2) test and the Hansen-J test are not rejected).

[Insert Table 5 and Table 6 here]

\section{Concluding remarks}

This paper is the first to examine whether the loan loss provisioning of Islamic banks is procyclical through the business cycle. Our empirical results show that loan loss provisions in Islamic banks are generally procyclical. Specifically, loan loss provisions decrease when economic growth is stronger. Such procyclicality is observed despite the fact that a dynamic provisioning system using the E-LLM as part of the AAOIFI compliance has been adopted by various countries at least since 2010. This may highlight that in general, the implementation of the E-LLM may not be effective yet in dealing with the procyclicality of loan loss provisioning. Accordingly, Islamic banks' provisioning behavior might deepen economic recessions, as loan loss provisions increase in response to a decline in economic growth.

Moreover, we find that loan loss provisions might also be used by Islamic bank managers to act opportunistically to increase bank capital. It is shown that higher capitalization tends to deteriorate loan loss reserves and reserves in Islamic banks consistent with the findings of Anandarajan et al. (2007) for conventional banks. Conversely, Islamic bank managers tend to inflate loan loss reserves and provisions when bank capital ratio declines. A closer investigation further reveals that the procyclicality of loan loss provisioning can be offset by higher Islamic bank capitalization. Specifically, Islamic banks with higher capitalization are more inclined 
to build up loan loss reserves and provisions during economic booms. Loan loss provisioning becomes countercyclical in this regard.

The findings of this paper provide various implications for bank regulators, managers, and investors. Because the use of the I-LLM and the E-LLM has become a lively debate (Bushman and Williams, 2012; Wezel, 2010), this paper provides insights to bank regulators, whether adopting a dynamic provisioning system using the E-LLM recommended by the AAOIFI should be made mandatory for Islamic banks around the world, in order to overcome procyclical issues that exacerbate bank risk taking during economic booms, and increase bank risk aversion in times of crisis.

This paper however casts doubts on the call for a dynamic provisioning system using the E-LLM to overcome procyclical issues for Islamic banks. Because the ELLM is influenced by managerial discretionary behavior using loan loss provisions, it may also cause opportunistic capital management (Bushman and Williams, 2012; Wezel, 2010) or earnings management (Elnahass et al., 2016). Likewise, our empirical results suggest that Islamic banks around the world could also be using loan loss provisions for opportunistic capital management purposes in which managers inflate loan loss reserves and provisions when bank capital declines. Yet, the procyclicality issues of loan loss provisions can already be resolved by enhancing bank capitalization, implying that opportunistic capital management using loan loss provisions can also be mitigated by enhancing bank capitalization. This is because only banks with lower capital ratios are likely to inflate loan loss reserves and provisions to maintain sufficient capitalization (Anandarajan et al., 2007; Bouvatier and Lepetit, 2012).

For Islamic bank managers and investors, the findings of this paper also highlight the importance of strengthening capitalization through increasing revenue generating capacity, efficiency and competitiveness in the market, because higher market power may increase the extent to which banks may raise more capital at least in the context of conventional banks (Berger et al., 2009; Soedarmono et al., 2013).

\section{References}

Ahmed, A.S. et al. (1999), "Bank loan loss provisions: A reexamination of capital management, earnings management and signaling effects", Journal of Accounting and Economics, 28, 1-25 
Anandarajan, A., I. Hasan, C. McCarthy (2007). "Use of loan loss provisions for capital, earnings management and signaling by Australian banks. Accounting and Finance, 47, 357-379

Arpa, M. et al. (2001), "The influence of macroeconomic developments on Austrian banks: implications for banking supervision”, BIS Papers, 1, 91-116.

Baltagi, B.H. (2005). Econometric Analysis of Panel Data, third ed. John Wiley \& Sons Ltd., Chichester.

Beaver, W.H. and E. Engel (1996), "Discretionary behavior with respect to allowances for loan losses and the behavior of security prices", Journal of Accounting and Economics, 22, 177-206.

Berger, A.N., L.F. Klapper, R.T. Ariss (2009). "Bank competition and financial stability" Journal of Financial Services Research 35, 99-118

Bikker, J.A. and P. Metzemakers (2005), "Bank provisioning behavior and procyclicality", Journal of International Financial Markets, Institutions and Money, $15,141-157$.

Blundell, R., \& Bond, S. (1998) "Initial conditions and moment restrictions in dynamic panel data models" Journal of Econometrics, 87, 115-143.

Bouvatier, V. and L. Lepetit (2012), "Effects of loan loss provisions on growth in bank lending: Some international comparisons", International Economics, 132, 91116.

Bouvatier, V. and L. Lepetit (2008), "Banks' procyclical behavior: does provisioning matter?", Journal of International Financial Markets, Institutions and Money, 18, 513-526.

Bushman, R. M., C.D. Willams, (2012). Accounting discretion, loan loss provisioning, and discipline of Banks' risk-taking. Journal of Accounting and Economics, 54 (1), 1-18.

Cavallo, M. and G. Majnoni (2002), "Do banks provision for bad loans in good times? Empirical evidence and policy implications" In: Levich, R., Majnoni, G., Reinhart, C. (Eds.), Ratings, Rating Agencies and the Global Financial System. Kluwer Academic Publishers, Boston, Dordrecht, London.

Collins, J., D. Shackelford, J. Wahlen (1995). "Bank differences in the coordination of regulatory capital, earnings and taxes". Journal of Accounting Research 33(2), 263-292.

Elnahass, M., M. Izzeldin, G. Steele., 2016. The expected loan loss model and earnings management: Evidence from contemporary practices. Working Paper, Lancaster University, UK 
Ernst and Young (2014). Impairment of Financial Instruments under IFRS 9. Release note (December). Available at www.ey.com.

Ernst and Young (2015). World Islamic Banking Competitiveness Report 2014-15. Available at: http://www.ey.com/EM/en/Industries/Financial-Services/Banking--Capital-Markets/EY-world-islamic-banking-competitiveness-report-2014-15.

Fonseca, A. R., F. González, F. (2008). "Cross-country determinants of bank income smoothing by managing loan-loss provisions". Journal of Banking and Finance, $32(2), 217-228$

Laeven, L. and G. Majnoni (2003), "Loan loss provisioning and economic slowdowns: too much, too late?", Journal of Financial Intermediation, 12, 178-197.

Lobo, G.L. and D.H. Yang (2001), "Bank managers' heterogeneous decisions on discretionary loan loss provisions", Review of Quantitative Finance and Accounting, $16,223-250$.

Parker, F. and H. Zhu (2012), "Loan loss provisioning practices of Asian banks", BIS Working Paper, 375.

Quttainah, M.A. et al. (2011), "Do Islamic Banks Employ Less Earnings Management?", Paper on Economic Research Forum, Oct, 2011.

Sarea, M. A., M. Hanefah (2013). The need of accounting standards for Islamic financial institutions: evidence from AAOIFI. Journal of Islamic Accounting and Business Research, 4(1), 64-76.

Soedarmono, W., F. Machrouh, A. Tarazi (2013). "Bank competition, crisis and risk taking: Evidence from emerging markets in Asia" Journal of International Financial Markets, Institutions and Money, 23, 196-221

Taktak, N. B., S.B.S. Zouari, S. B. S., A. Boudriga (2010). Do Islamic banks use loan loss provisions to smooth their results? Journal of Islamic Accounting and Business Research, 1 (2), 114-127.

Wezel, T. (2010). Dynamic Loan Loss Provisions in Uruguay: Properties, Shock Absorption Capacity and Simulations Using Alternative Formulas. Working Chapter, Washington: International Monetary Fund (IMF): WP/10/125

Windmeijer, F. (2005) "A finite sample correction for the variance of linear efficient two-step GMM estimators" Journal of Econometrics, 126, 25-51.

Zoubi, T. A.. O. Al-Khazali (2007). Empirical testing of the loss provisions of banks in the GCC Region. Managerial Finance, 33 (7), 200-511. 
Table 1. Descriptive statistics

\begin{tabular}{|c|c|c|c|c|c|c|}
\hline Variable & Definition & Obs & Mean & Std. Dev. & Min & Max \\
\hline LLPTA & Ratio of loan loss provisions to total assets & 694 & 0.0075819 & 0.0151546 & -0.126497 & 0.1412412 \\
\hline LLRTA & Ratio of loan loss reserves to total assets & 702 & 0.0264963 & 0.0379222 & 0.000113 & 0.4414414 \\
\hline$L T A$ & Ratio of total loans to total assets & 999 & 0.4747414 & 0.2548028 & 0.00000241 & 0.9927928 \\
\hline$N P L$ & Ratio of non-performing loans to total assets & 417 & 0.0870674 & 0.1334875 & 0.0000941 & 0.831972 \\
\hline GROWTH & Real gross domestic product growth & 1684 & 0.0469603 & 0.0542033 & -0.413 & 0.465 \\
\hline CAP & Ratio of total equity to total assets & 1050 & 0.2621883 & 0.2636642 & -0.5892856 & 1 \\
\hline EBTP & Ratio of earning before tax and provisions to total assets & 724 & 0.0182807 & 0.043667 & -0.4108263 & 0.2611041 \\
\hline SIGN & Signaling variable & 585 & 0.0044359 & 0.0427708 & -0.3834767 & 0.3486663 \\
\hline
\end{tabular}

Table 2. Correlation structure

\begin{tabular}{|c|c|c|c|c|c|c|c|c|}
\hline Variables & LLPTA & LLRTA & $L T A$ & NPL & GROWTH & $C A P$ & $E B T P$ & SIGN \\
\hline LLPTA & 1 & & & & & & & \\
\hline LLRTA & 0.2766 & 1 & & & & & & \\
\hline LTA & 0.143 & 0.3512 & 1 & & & & & \\
\hline$N P L$ & 0.3699 & 0.7021 & 0.0009 & 1 & & & & \\
\hline GROWTH & -0.0648 & -0.002 & 0.0428 & -0.0077 & 1 & & & \\
\hline$C A P$ & -0.1161 & 0.1479 & 0.0044 & 0.1388 & 0.0135 & 1 & & \\
\hline EBTP & -0.1322 & 0.0619 & 0.3473 & -0.1635 & 0.1967 & -0.0158 & 1 & \\
\hline SIGN & 0.0123 & -0.004 & 0.0188 & -0.1135 & -0.0321 & -0.0018 & -0.6156 & 1 \\
\hline
\end{tabular}


Table 3. The procyclicality of loan loss provisions

\begin{tabular}{|c|c|c|}
\hline \multirow[b]{2}{*}{ Explanatory variables } & \multicolumn{2}{|c|}{ Dependent variables } \\
\hline & LLPTA & LLRTA \\
\hline $\operatorname{LLPTA}(-1)$ & $\begin{array}{l}0.6973 * * * \\
(0.144)\end{array}$ & \\
\hline $\operatorname{LLRTA}(-1)$ & & $\begin{array}{l}0.7768 * * * \\
(0.035)\end{array}$ \\
\hline$L T A$ & $\begin{array}{l}0.0042 * * * \\
(0.002)\end{array}$ & $\begin{array}{l}0.0091 * * * \\
(0.002)\end{array}$ \\
\hline$N P L$ & $\begin{array}{l}0.0130 \\
(0.022)\end{array}$ & $\begin{array}{l}0.0619 \text { *** } \\
(0.013)\end{array}$ \\
\hline GROWTH & $\begin{array}{l}-0.0245^{* *} \\
(0.009)\end{array}$ & $\begin{array}{l}-0.0500 * * * \\
(0.017)\end{array}$ \\
\hline Observations & 311 & 310 \\
\hline Number of banks & 73 & 72 \\
\hline $\operatorname{AR}(2)$ test ( $p$-value) & 0.981 & 0.350 \\
\hline Hansen-J test ( $p$-value) & 0.420 & 0.126 \\
\hline
\end{tabular}

Notes: The definition of variables follows Table 1. Regressions are carried out using the system GMM following Blundell and Bond (1998) by taking orthogonal deviation of instruments into account and hence, we control for cross-sectional fixed effects. Models are valid if the AR(2) and Hansen-J test are not significant. $* * *, * *, *$ indicate significance at the $1 \%, 5 \%$, and $10 \%$ levels, respectively. Standard errors are in parentheses. 
Table 4. Do capital management, income smoothing and signaling using loan loss provisions alter procyclical effects?

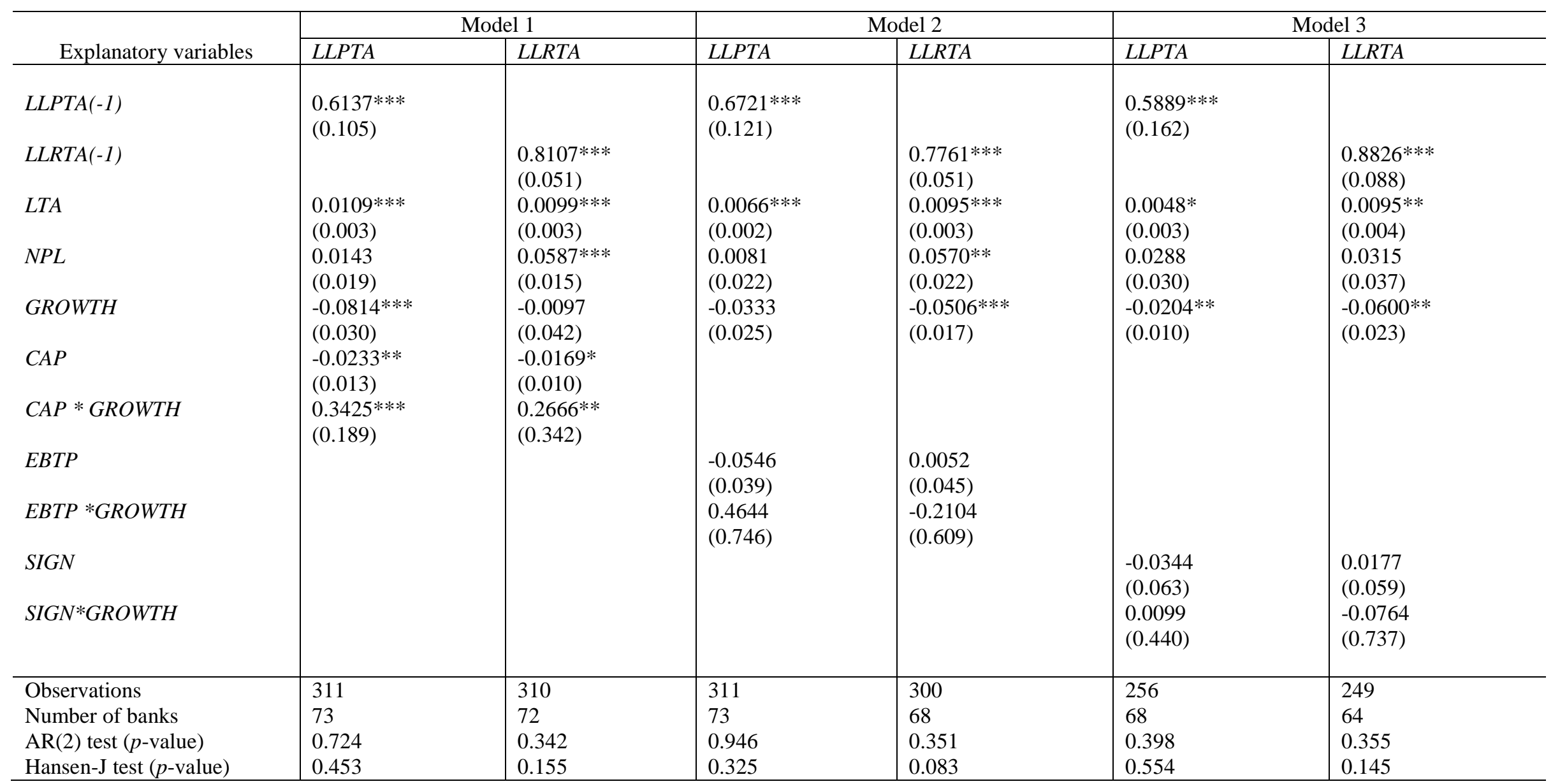

Notes: The definition of variables follows Table 1. Regressions are carried out using the system GMM following Blundell and Bond (1988) by taking orthogonal deviation of instruments into account and hence, we control for cross-sectional fixed effects. Models are valid if the AR(2) and Hansen-J test are not significant. $* * *, * *, *$ indicate significance at the $1 \%, 5 \%$, and $10 \%$ levels, respectively. Standard errors are in parentheses. 
Table 5. The procyclicality of loan loss provisions (First-difference transformation)

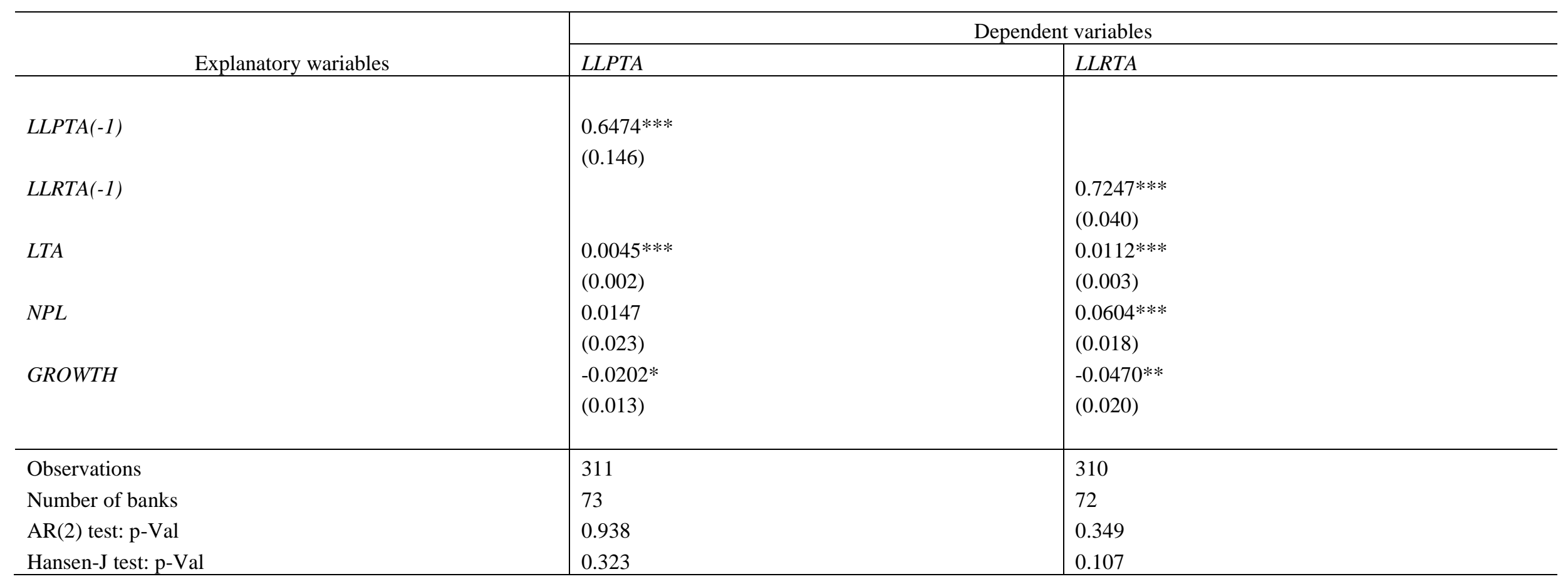

Notes: The definition of variables follows Table 1. Regressions are carried out using the system GMM following Blundell and Bond (1998) by taking firstdifference transformation of instruments into account and hence, we control for cross-sectional fixed effects. Models are valid if the AR(2) and Hansen-J test are not significant. $* * *, * *, *$ indicate significance at the $1 \%, 5 \%$, and $10 \%$ levels, respectively. Standard errors are in parentheses. 
Table 6. Effects of capital management, income smoothing and signaling on procyclical issues (First-difference transformation)

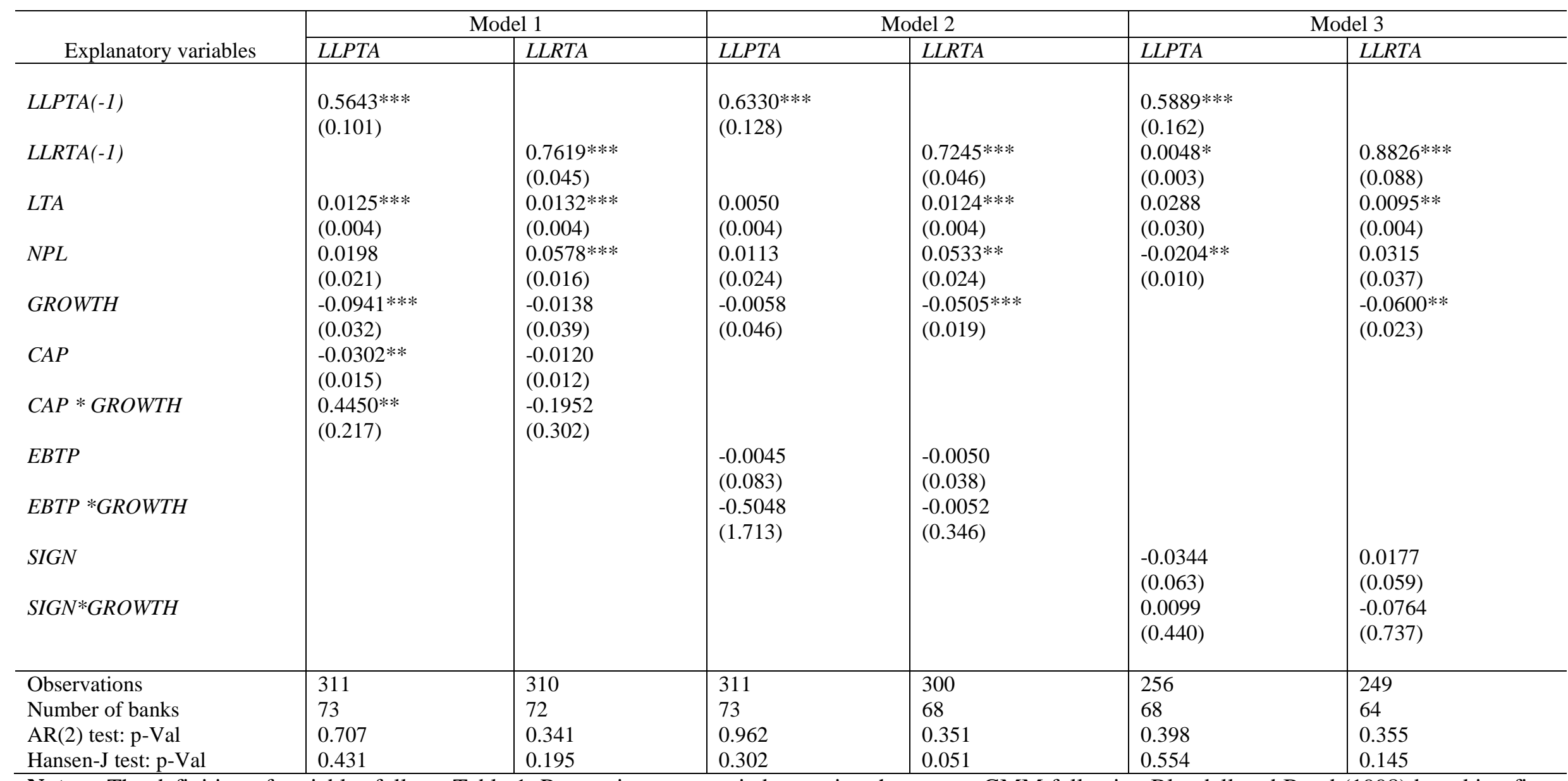

Notes: The definition of variables follows Table 1. Regressions are carried out using the system GMM following Blundell and Bond (1998) by taking firstdifference transformation of instruments into account and hence, we control for cross-sectional fixed effects. Models are valid if the AR(2) and Hansen-J test are not significant. $* * *, * *, *$ indicate significance at the $1 \%, 5 \%$, and $10 \%$ levels, respectively. Standard errors are in parentheses. 